\title{
Synthesis, Spectral, Characterization, DFT and Biological Studies of New 3-[(3-Chlorophenyl)-hydrazono]-pentane-2,4-dione Metal Complexes
}

\author{
Sadeek. A. Sadeek*, Wael. A. Zordok, Ahmed. F. El-Farargy, and Sameh. I. El-Desoky ${ }^{\dagger}$ \\ Department of Chemistry, Faculty of Science, Zagazig University, Zagazig, Egypt. \\ ${ }^{*}$ E-mail: s_sadeek@zu.edu.eg \\ †Department of Quality Control, Ceramica Royal, Egypt \\ (Received November 6, 2013; Accepted January 24, 2014)
}

\begin{abstract}
A new series of metal complexes of V(IV), Pd(II), Pt(IV), Ce(IV) and U(VI) with 3-[(3-chlorophenyl)-hydrazono]-pentane-2,4-dione (Cphpd) were synthesized and characterized by elemental analysis, molar conductivity, magnetic moment measurements, UV-vis, FT-IR and ${ }^{1} \mathrm{H}$ NMR as well as TG-DTG techniques. The data indicated that the Cphpd acts as a bidentate ligand through the hydrazono nitrogen and one keto oxygen. The kinetic parameters have been evaluated by using Coats Redfern (CR) and Horowitz-Metzeger (HM) methods. The thermodynamic data reflected the thermal stability for all complexes. The calculated bond length and the bond stretching force constant, $\mathrm{F}(\mathrm{U}=\mathrm{O})$, values for $\mathrm{UO}_{2}$ bond are $0.775 \AA$ and $286.95 \mathrm{Nm}^{-1}$. The bond lengths, bond angles, dipole moment and the lowest energy model structure of the complexes have been determined with DFT calculations. The antimicrobial activity of the synthesized ligand and its complexes were screened.
\end{abstract}

Key words: Cphpd, Transition metal complexes, FT-IR, Mass spectra

\section{INTRODUCTION}

Recently, chlorinated organic compounds have attracted attention due to the ability of chlorine to act as polar hydrogen or hydroxyl mimic. Therefore, substitution of hydrogen by chlorine has been a strategy in designing molecules for biological activity studies. ${ }^{1}$ Benzenediazonium chloride is excellent starting material for the synthesis of 3-[(3chlorophenyl)-hydrazono]-pentane-2,4-dione (Cphpd) (Scheme 1) via the reaction of 3-chlorobenzenediazonium chloride with acetyl acetone. ${ }^{1}$

In recent years the chemistry of heterocyclic compounds are well known for their diverse therapeutic properties and exhibited antibacterial, anticancer, antiulcer, diuretics, anticonvulsant, antihypertensive, antitumor, antifungal, antiAIDS and antiviral properties. ${ }^{2}$ Metal chelates play an important role in various fields of chemical, biological and technological sciences on coordination, ligands might improve their bioactivity profiles, while some inactive ligand may acquire pharmacological properties. Activity of various anti-inflammatory drugs existing in market has enhanced after complexation with transition metal ion. ${ }^{3}$

A detailed literature research has shown that no work is reported on the 3-[(3-chlorophenyl)-hydrazono]-pentane2,4-dione (Cphpd). Thus, our aim was to synthesize and characterize the complexes of V(IV), Pd(II), Pt(IV), Ce(IV) and U(VI) with Cphpd in order to investigate their mag-<smiles>CC(=O)C(=NNc1cccc(Cl)c1)C(C)=O</smiles>

3-[(3-chloro-phenyl)-hydrazono]-pentane-2,4-dione

Scheme 1.

netic, spectroscopic and thermal techniques in an attempt to examine the mode of binding. Density functional theory (DFT) was used to compute the cation type influence on theoretical parameters of V(IV), $\mathrm{Pd}(\mathrm{II}), \mathrm{Pt}(\mathrm{IV})$ and $\mathrm{Ce}$ (IV) complexes and detect the exact structure of these complexes. Indeed, the biological activity of the ligand and its complexes were screened against selected kinds of bacteria and fungi.

\section{EXPERIMENTAL}

\section{Materials}

All chemicals used for the preparation of the complexes were of analytical reagent grade, commercially available 
from different sources and used without further purification.

\section{Synthesis \\ Synthesis of metal complexes}

The black solid complex $\left[\mathrm{VO}(\mathrm{Cphpd})_{2}\left(\mathrm{H}_{2} \mathrm{O}\right)\right] \mathrm{SO}_{4}$ was prepared by adding $1 \mathrm{mmol}(0.18 \mathrm{~g})$ of $\mathrm{VOSO}_{4} \cdot \mathrm{H}_{2} \mathrm{O}$ in $20 \mathrm{ml}$ acetone drop-wisely to a stirred clear solution of Cphpd (2 $\mathrm{mmol}, 0.48 \mathrm{~g}$ ) at room temperature for one day. The solution was left for slow evaporation, the black precipitate formed was filtered off, washed with doubly distilled water several times and dried in vacuum over $\mathrm{CaCl}_{2}$ in a desiccator. The deep-brown, deep-brown, olive-green and brown solid complexes of $\left[\mathrm{Pd}(\mathrm{Cphpd})_{2}\left(\mathrm{H}_{2} \mathrm{O}\right)_{2}\right] \mathrm{Cl}_{2} \cdot 2 \mathrm{H}_{2} \mathrm{O}$, $\left[\mathrm{Pt}(\mathrm{Cphpd})_{2} \mathrm{Cl}_{2}\right] \mathrm{Cl}_{2}$, $\left[\mathrm{Ce}(\mathrm{Cphpd})_{2}\left(\mathrm{H}_{2} \mathrm{O}\right)_{2}\right]\left(\mathrm{SO}_{4}\right)_{2}$ and $\left[\mathrm{UO}_{2}(\mathrm{Cphpd})_{2}\right]\left(\mathrm{NO}_{3}\right)_{2} \cdot 3 \mathrm{H}_{2} \mathrm{O}$ were prepared in a similar manner described above by using acetone as a solvent and using $\mathrm{PdCl}_{2}, \mathrm{PtCl}_{4}, \mathrm{Ce}\left(\mathrm{SO}_{4}\right)_{2}$ and $\mathrm{UO}_{2}\left(\mathrm{NO}_{3}\right)_{2} \cdot 6 \mathrm{H}_{2} \mathrm{O}$ respectively, in 1:2 molar ratio (M: Cphpd). All compounds were characterized by their elemental analysis, molar conductance, magnetic moment, IR, ${ }^{1} \mathrm{H}$ NMR, electronic, mass spectra as well as thermal analysis.

\section{Instrumentation-Physical Measurements}

$\mathrm{C}, \mathrm{H}$ and $\mathrm{N}$ analyses was carried out on a Perkin Elmer CHN 2400. The percentage of the metal ions were determined gravimetrically by transforming the solid products into metal oxide or sulphate and also determined by using atomic absorption method. Spectrometer model PYE-UNICAM SP 1900 fitted with the corresponding lamp was used for this purpose. IR spectra were recorded on FT-IR 460 PLUS (KBr discs) in the range from $4000-400 \mathrm{~cm}^{-1},{ }^{1} \mathrm{H}$ NMR spectra were recorded on Varian Mercury VX-300 NMR Spectrometer using DMSO- $\mathrm{d}_{6}$ as solvent. TGA-DTG measurements were carried out with heating rate being controlled at $10^{\circ} \mathrm{C} \mathrm{min}{ }^{-1}$ under $\mathrm{N}_{2}$ atmosphere from room temperature to $800{ }^{\circ} \mathrm{C}$ using TGA-50H Shimadzu. The mass of sample was accurately weighted out in an aluminum crucible. Electronic spectra were obtained using UV-3101PC Shimadzu. The solid reflection spectra were recorded with $\mathrm{KBr}$ pellets. Magnetic measurements were carried out on a Sherwood scientific magnetic balance using Gouy method using $\mathrm{Hg}\left[\mathrm{Co}(\mathrm{SCN})_{4}\right]$ as calibrant. Melting points were determined on an Electrothermal-9100 apparatus. Molar conductivities of the solution of the ligand and metal complexes in DMSO at $1 \times 10^{-3} \mathrm{M}$ were measured on CONSORT K410.

\section{Biological Activity}

Antibacterial activity of the ligands and their metal complexes was investigated by a modied method of Beecher and Wong, ${ }^{4}$ against different bacterial species, such as S. aureus $\mathrm{K} 1$, B. subtilis K22, E. Coli $\mathrm{K} 32$ and P. aeruginosa $\mathrm{SW} 1$. And antifungal screening was studied against two species, aspergillus flarus (A. flarus) and aspergillus fumigates (A. fumigates), the tested microorganisms isolates were isolated from Egyptian soil and identified according to the standard mycological and bacteriological keys for identification of fungi and bacteria as stock cultures in the microbiology laboratory, Faculty of Science, Zagazig University. The nutrient agar medium for antibacterial was MüllerHington agar (30.0\% beef extract, $1.75 \%$ Casein hydrolysate, $0.15 \%$ starch and $1.7 \%$ agar) and for antifungal $(3 \%$ Sucrose, $0.3 \% \mathrm{NaNO}_{3}, 0.1 \% \mathrm{~K}_{2} \mathrm{HPO}_{4}, 0.05 \% \mathrm{KCl}, 0.001 \%$ $\mathrm{FeSO}_{4}, 2 \%$ Agar-Agar) was prepared and then cooled to $47^{\circ} \mathrm{C}$ and seeded with tested microorganisms. After solidication $5 \mathrm{~mm}$ diameter holes were punched by a sterile corkborer. The investigated compounds, i.e., ligands and their complexes were introduced in holes (only $100 \mu \mathrm{L}$ ) after being dissolved in DMSO at $10^{-3} \mathrm{M}$. These culture plates were then incubated at $37^{\circ} \mathrm{C}$ for $20 \mathrm{~h}$ for bacteria and seven days at $30^{\circ} \mathrm{C}$ for fungi. The activity was determined by measuring the diameter of the inhibition zones (in $\mathrm{mm}$ ). Growth inhibition was calculated with reference to the positive control, i.e., ligands.

\section{RESULTS AND DISCUSSION}

The complexes of 3-[(3-chlorophenyl)-hydrazono]-pentane-2,4-dione (Cphpd) with V(IV), Pd(II), Pt(IV), Ce(IV) and U(VI) were synthesized and studied. Single x-ray diffraction measurements could not be done due to the formation of non suitable crystals. The stoichiometry of the complexes was established on the basis of their elemental analysis (Table 1). The formulas pattern and the geometry of the complexes were assigned on the basis of physicochemical parameters such as conductance measurements, magnetic susceptibilities and spectral measurements. The magnetic susceptibility measurments for all the five complexes indicated that the complexes were found as diamagnetism except $\mathrm{V}(\mathrm{IV})$ and $\mathrm{Pd}(\mathrm{II})$ complexes have magnetic moments of 1.73 and 3.00 B.M. at room temperature, respectively. The molar conductance values of Cphpd and their metal complexes measured in DMSO at room temperature were found from 2.14 to $234.59 \mathrm{~S} \mathrm{~cm}^{2} \mathrm{~mol}^{-1}$ (Table 1). The molar conductance values showed that all the complexes were electrolytes. ${ }^{5}$ Qualitative reactions for the isolated complexes indicated the presence of sulphate, chloride and nitrate ions as counter ions which agreed well with the 
Table 1. Elemental analysis and physico-analytical data for Cphpd and its metal complexes

\begin{tabular}{|c|c|c|c|c|c|c|c|c|c|c|}
\hline \multirow{2}{*}{$\begin{array}{l}\text { Compounds } \\
\text { M.Wt. (M.F.) }\end{array}$} & \multirow{2}{*}{ Yield\% } & \multirow{2}{*}{$\mathrm{Mp} /{ }^{\circ} \mathrm{C}$} & \multirow{2}{*}{ Color } & \multicolumn{5}{|c|}{ Found (Calcd.) (\%) } & \multirow{2}{*}{$\mu_{\mathrm{eff}}(\mathrm{B} . \mathrm{M})$} & \multirow{2}{*}{$\begin{array}{l}\Lambda\left(\mathrm{S} \mathrm{cm}^{2}\right. \\
\left.\mathrm{mol}^{-1}\right)\end{array}$} \\
\hline & & & & $\mathrm{C}$ & $\mathrm{H}$ & $\mathrm{N}$ & $\mathrm{Cl}$ & $\mathrm{M}$ & & \\
\hline $\begin{array}{l}\text { Cphpd } \\
238.50, \mathrm{C}_{11} \mathrm{H}_{11} \mathrm{~N}_{2} \mathrm{O}_{2} \mathrm{Cl}\end{array}$ & - & 110 & Buff & $\begin{array}{l}55.27 \\
(55.34)\end{array}$ & $\begin{array}{l}4.59 \\
(4.61)\end{array}$ & $\begin{array}{l}11.71 \\
(11.74)\end{array}$ & $\begin{array}{l}14.80 \\
(14.88)\end{array}$ & - & Diamagnetic & 2.14 \\
\hline $\begin{array}{l}{\left[\mathrm{VO}\left(\mathrm{C}_{11} \mathrm{H}_{11} \mathrm{~N}_{2} \mathrm{O}_{2} \mathrm{Cl}\right)_{2}\left(\mathrm{H}_{2} \mathrm{O}\right)\right] \mathrm{SO}_{4}} \\
658, \mathrm{VC}_{22} \mathrm{H}_{24} \mathrm{~N}_{4} \mathrm{O}_{10} \mathrm{Cl}_{2} \mathrm{~S}\end{array}$ & 73 & 119 & Black & $\begin{array}{l}39.99 \\
(40.12)\end{array}$ & $\begin{array}{l}3.53 \\
(3.64)\end{array}$ & $\begin{array}{l}8.39 \\
(8.51)\end{array}$ & $\begin{array}{l}10.66 \\
(10.79)\end{array}$ & $\begin{array}{l}7.64 \\
(7.74)\end{array}$ & 1.73 & 109.69 \\
\hline $\begin{array}{l}{\left[\mathrm{Pd}\left(\mathrm{C}_{11} \mathrm{H}_{11} \mathrm{~N}_{2} \mathrm{O}_{2} \mathrm{Cl}\right)_{2}\left(\mathrm{H}_{2} \mathrm{O}\right)_{2}\right] \mathrm{Cl}_{2} \cdot 2 \mathrm{H}_{2} \mathrm{O}} \\
726.42, \mathrm{PdC}_{22} \mathrm{H}_{30} \mathrm{~N}_{4} \mathrm{O}_{8} \mathrm{Cl}_{4}\end{array}$ & 90 & 120 & Deep-brown & $\begin{array}{l}36.29 \\
(36.34)\end{array}$ & $\begin{array}{l}4.03 \\
(4.12)\end{array}$ & $\begin{array}{l}7.63 \\
(7.70)\end{array}$ & $\begin{array}{l}19.49 \\
(19.54)\end{array}$ & $\begin{array}{l}14.55 \\
(14.64)\end{array}$ & 3.00 & 163.71 \\
\hline $\begin{array}{l}{\left[\mathrm{Pt}\left(\mathrm{C}_{11} \mathrm{H}_{11} \mathrm{~N}_{2} \mathrm{O}_{2} \mathrm{Cl}_{2} \mathrm{Cl}_{2}\right] \mathrm{Cl}_{2}\right.} \\
\text { 814.08, } \mathrm{PtC}_{22} \mathrm{H}_{22} \mathrm{~N}_{4} \mathrm{O}_{4} \mathrm{Cl}_{6}\end{array}$ & 78.6 & 140 & Deep-brown & $\begin{array}{l}32.31 \\
(32.42)\end{array}$ & $\begin{array}{l}2.59 \\
(2.70)\end{array}$ & $\begin{array}{l}6.77 \\
(6.87)\end{array}$ & $\begin{array}{l}26.06 \\
(26.16)\end{array}$ & $\begin{array}{l}23.77 \\
(23.96)\end{array}$ & Diamagnetic & 160.33 \\
\hline $\begin{array}{l}{\left[\mathrm{Ce}\left(\mathrm{C}_{11} \mathrm{H}_{11} \mathrm{~N}_{2} \mathrm{O}_{2} \mathrm{Cl}\right)_{2}\left(\mathrm{H}_{2} \mathrm{O}\right)_{2}\right]\left(\mathrm{SO}_{4}\right)_{2}} \\
\text { 845.12, } \mathrm{CeC}_{22} \mathrm{H}_{26} \mathrm{~N}_{4} \mathrm{O}_{14} \mathrm{Cl}_{2} \mathrm{~S}_{2}\end{array}$ & 64 & 120 & Olive-green & $\begin{array}{l}31.12 \\
(31.23)\end{array}$ & $\begin{array}{l}3.03 \\
(3.07)\end{array}$ & $\begin{array}{l}6.51 \\
(6.62)\end{array}$ & $\begin{array}{l}8.35 \\
(8.40)\end{array}$ & $\begin{array}{l}16.38 \\
(16.57)\end{array}$ & Diamagnetic & 227.50 \\
\hline $\begin{array}{l}{\left[\mathrm{UO}_{2}\left(\mathrm{C}_{11} \mathrm{H}_{11} \mathrm{~N}_{2} \mathrm{O}_{2} \mathrm{Cl}\right)_{2}\right]\left(\mathrm{NO}_{3}\right)_{2} .3 \mathrm{H}_{2} \mathrm{O}} \\
925.03, \mathrm{UC}_{22} \mathrm{H}_{28} \mathrm{~N}_{6} \mathrm{O}_{15} \mathrm{Cl}_{2}\end{array}$ & 81.4 & 198 & Brown & $\begin{array}{l}28.58 \\
(28.60)\end{array}$ & $\begin{array}{l}3.00 \\
(3.03)\end{array}$ & $\begin{array}{l}9.07 \\
(9.10)\end{array}$ & $\begin{array}{l}7.55 \\
(7.69)\end{array}$ & $\begin{array}{l}25.67 \\
(25.78)\end{array}$ & Diamagnetic & 234.59 \\
\hline
\end{tabular}

results of molar conductance and infrared data.

\section{Spectroscopic Studies \\ IR absorption spectra}

Before discussing the assignments of the infrared spectra of the free ligand (Cphpd) and its metal complexes, the proposed structures of the complexes must be considered. Here, metal ions reacted with Cphpd forming complexes of monomeric structure where the metal ions are six coordinated.

The proposed structure of $\left[\mathrm{M}(\mathrm{Cphpd})_{2}\left(\mathrm{H}_{2} \mathrm{O}\right)_{2}\right]^{+\mathrm{n}}(\mathrm{M}=$ $\mathrm{Pd}(\mathrm{II})$ and $\mathrm{Ce}(\mathrm{IV})),\left[\mathrm{Pt}(\mathrm{Cphpd})_{2} \mathrm{Cl}_{2}\right]^{+2}$ and $\left[\mathrm{UO}_{2}(\mathrm{Cphpd})_{2}\right]^{+2}$ complexes, (Scheme 2$)$, contain only a plane of symmetry

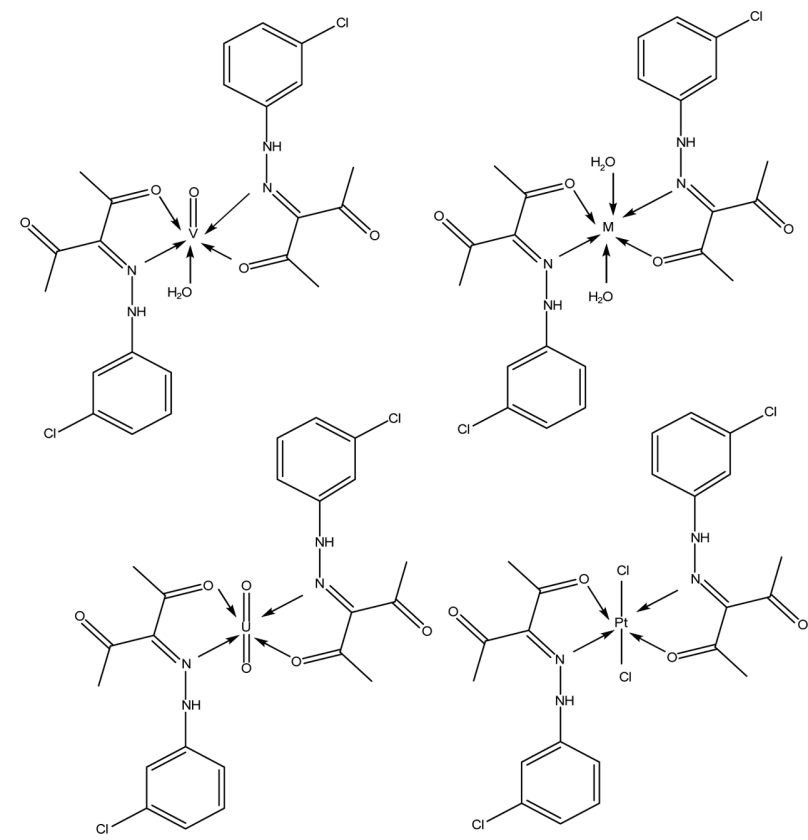

Scheme 2. The proposed coordination mode of V(IV), Pt(IV), $\mathrm{U}(\mathrm{VI})$ and $\mathrm{M}=\mathrm{Pd}(\mathrm{II})$ and $\mathrm{Ce}(\mathrm{IV})$ with Cphpd. and hence the four complexes may belong to $\mathrm{C}_{\mathrm{S}}$ symmetry but $\mathrm{V}(\mathrm{IV})$ complex may belong to $\mathrm{C}_{1}{ }^{6-14}$ The $\mathrm{C}_{\mathrm{s}}$ complexes are expected to display 177 for $\mathrm{Pd}(\mathrm{II})$ and $\mathrm{Ce}(\mathrm{IV})$ and 165 for Pt(IV) and U(VI) vibrational fundamentals and all vibrations are distributed between motions of the types $A^{`}$ and $A^{\prime \prime}$, all are monodegenrate, infrared and Raman active. The data showed that the $v_{a s}(\mathrm{U}=\mathrm{O})$ and $v_{s}(\mathrm{U}=\mathrm{O})$ absorption bands occur at 941 and $822 \mathrm{~cm}^{-1}$ as a very strong singlet and strong bands, respectively. These assignments for the stretching vibrations of the uranyl group, agreed quite well with those known for many dioxouranium (VI) complexes. ${ }^{7,915,16}$ The $v(\mathrm{U}=\mathrm{O})$ of the uranyl unit in the $\left[\mathrm{UO}_{2}(\mathrm{Cphpd})_{2}\right]^{+2}$ complex occurred at lower frequency values compared with those for the same unit, $\mathrm{UO}_{2}$, in simple salts and this was consistent with the formation of the complex. ${ }^{7}$ The $v_{\mathrm{s}}(\mathrm{U}=\mathrm{O})$ value was used to calculate both the bond length and the bond stretching force constant, $\mathrm{F}(\mathrm{U}=\mathrm{O})$, for $\mathrm{UO}_{2}$ bond in our complex according to known methods. ${ }^{7,9}$ The calculated bond length and force constant values are $0.775 \AA$ and $286.95 \mathrm{Nm}^{-1}$, respectively.

The infrared spectrum of free ligand shows two bands at 1490 and $1670 \mathrm{~cm}^{-1}$ which attributed to the stretching vibration of $v(\mathrm{C}=\mathrm{N})$ for hydrazono group and $v(\mathrm{C}=\mathrm{O})$ for two equivalent keto groups. ${ }^{9,10}$ Upon comparison of the IR spectra of the complexes with those of free ligand the shift of $v(\mathrm{C}=\mathrm{N})$ to higher frequency values $\left(1508\right.$ and $\left.1512 \mathrm{~cm}^{-1}\right)$ confirming that the ligand molecule coordinated to metal ion through the nitrogen atom of hydrazono group. The shift of $v(\mathrm{C}=\mathrm{N})$ to higher frequency values may indicate an increase of $\mathrm{C}=\mathrm{N}$ bond strength upon coordination. ${ }^{7-11}$ The possibility that the electron density on the nitrogen atom was decreased upon coordination to metal ions means a decrease in the electron repulsion between the nitrogen lone pair and the double bond electrons leading to a stronger $\mathrm{C}=\mathrm{N}$ 
bond then, a higher frequency bond. Also, the shift of $v(\mathrm{C}=\mathrm{O})$ to lower frequency value $\left(1632\right.$ and $\left.1639 \mathrm{~cm}^{-1}\right)$ in the spectra of the complexes may indicate a decrease of the $\mathrm{C}=\mathrm{O}$ bond strength upon coordination. ${ }^{9}$ The bands in the range $3489-3400 \mathrm{~cm}^{-1}$ in the spectra of the complexes can be attributed to the $v(\mathrm{O}-\mathrm{H})$ vibration of the water molecules. ${ }^{11}$ The $v(\mathrm{~N}-\mathrm{H})$ vibration appears in the region of $3310-3222 \mathrm{~cm}^{-1}$ and the stretching vibrations $v(\mathrm{C}-\mathrm{H})$ of phenyl and methyl groups are assigned as a number of bands in the region $3178-2920 \mathrm{~cm}^{-1} .^{12}$

The spectra of the isolated solid complexes showed a group of new bands with different intensities which characteristics for $v(\mathrm{M}-\mathrm{O})$ and $v(\mathrm{M}-\mathrm{N})$. The $v(\mathrm{M}-\mathrm{O})$ and $v(\mathrm{M}-$ N) bands observed at 632,590 and $522 \mathrm{~cm}^{-1}$ for V(IV), at 683,625 and $590 \mathrm{~cm}^{-1}$ for $\mathrm{Pd}(\mathrm{II})$, at 679,575 and $448 \mathrm{~cm}^{-1}$ for Pt(II), at 667, 533 and 489 for Ce(IV) and at 683, 625 and $590 \mathrm{~cm}^{-1}$ for U(VI) (Table S3) which are absent in the spectrum of Cphpd. ${ }^{6-12}$

\section{Electronic spectra}

The UV-visible spectral data of the free ligand (Cphpd) and its metal complexes were recorded (Table 2). The electronic absorption spectrum of the Cphpd was reflected by three absorption bands at 262, 281 and 374 . The first band at $262 \mathrm{~nm}$ may be attributed to $\pi-\pi^{*}$ (phenyl ring) transition and the second two bands are assigned to $\mathrm{n}-\pi^{*}$ $(-\mathrm{NH},-\mathrm{C}=\mathrm{O}$ and $-\mathrm{C}=\mathrm{N})$ transition, these transitions occur in case of unsaturated hydrocarbons which contain ketone and cyanide group. ${ }^{17}$ The intraligand bands were slightly shifted to longer wavelength (bathochromic shift) and to lower values (hypsochromic shift) upon complexation and the presence of new bands in the reflection spectra of all complexes indicated the formation of their metal complexes. The new bands in the range from 419 to $499 \mathrm{~nm}$ may be assigned to the ligand to metal charge-transfer. ${ }^{18,19}$ The electronic spectra of V(IV), Pd(II) and Pt(IV) complexes showed bands from 515 to $579 \mathrm{~nm}$. These bands were assigned to $\mathrm{d}-\mathrm{d}$ transitions.

\section{Nuclear magnetic resonance $\left({ }^{1} \mathrm{H}\right.$ NMR)}

The ${ }^{1} \mathrm{H}$ NMR spectra of Cphpd and its metal complexes confirms the suggested structures. The proton of $-\mathrm{NH}$ signal for the Pt(IV), Ce(IV) and U(VI) complexes observed at $\delta: 14.53 \mathrm{ppm}\left(\mathrm{s}, 2 \mathrm{H},-\mathrm{N} \underline{\mathrm{H}}\right.$, exchange with $\left.\mathrm{D}_{2} \mathrm{O}\right)$ showed no big differences as compared to that of the free ligand at $\delta: 13.24 \mathrm{ppm}\left(\mathrm{s}, 1 \mathrm{H},-\mathrm{N} \underline{\mathrm{H}}\right.$, exchange with $\left.\mathrm{D}_{2} \mathrm{O}\right)$. This enhances the hypothesis that $-\mathrm{NH}$ is not the coordinating group. The new signals are observed in the range $\delta: 3.24-3.51 \mathrm{ppm}$ due to presence of $\mathrm{H}_{2} \mathrm{O}$ molecules in all complexes. On the other hand, the values of protons of $-\mathrm{CH}$ aliphatic observed in the range of $2.07-2.58 \mathrm{ppm}\left(\mathrm{s}, 12 \mathrm{H},-\mathrm{C}_{3}\right)$ and those of aromatic ring in the range of $6.81-7.88 \mathrm{ppm}(\mathrm{m}, 8 \mathrm{H}$, $\mathrm{Ar}-\underline{\mathrm{H}}$ ) increased and the intensity of signals is increased, as shown in Table $3 .{ }^{20}$ From ${ }^{1} \mathrm{H}$ NMR and FT-IR results, it was proposed that the Cphpd coordinated to the central metal ion as bidentate ligand through the nitrogen atom of hydrazono group and oxygen atom of one keto group. ${ }^{21}$

\section{Thermal studies}

Thermogravimetric (TGA) and differential thermogravimetric (DTG) analyses for Cphpd and its metal complexes were carried out. Table 4 gives the maximum temperature values for decomposition along with the corresponding weight loss values for each step of the decomposition reaction. The Cphpd is thermally stable up to $135^{\circ} \mathrm{C}$ and the decomposition started at $135^{\circ} \mathrm{C}$ and finished at $550{ }^{\circ} \mathrm{C}$ with one stage at one maximum $205^{\circ} \mathrm{C}$ and is accompanied by a weight loss of $59.54 \%$ (Fig. S4(A)).

Table 2. UV-vis spectral data of the free ligand Cphpd and its metal complexes

\begin{tabular}{lllllll}
\hline \multirow{2}{*}{ Assignments (nm) } & \multirow{2}{*}{ Cphpd } & \multicolumn{5}{c}{ Metal complexes with } \\
\cline { 2 - 7 } & & $\mathrm{V}(\mathrm{IV})$ & $\mathrm{Pd}(\mathrm{II})$ & $\mathrm{Pt}(\mathrm{IV})$ & $\mathrm{Ce}(\mathrm{IV})$ & $\mathrm{U}(\mathrm{VI})$ \\
\hline$\pi-\pi^{*}$ transitions & 262 & 272 & 252 & 259 & 210,233 & 248 \\
$\mathrm{n}-\pi^{*}$ transitions & 281,374 & 291,394 & 364 & 292,370 & 314 & 381,386 \\
Ligand-metal charge transfer & - & 439,493 & 459,499 & 419,438 & 495 & 475,483 \\
$\mathrm{~d}-\mathrm{d}$ transitions & - & 524,566 & 577 & $515,522,579$ & - & - \\
\hline
\end{tabular}

Table 3. Selected ${ }^{1} \mathrm{H}$ NMR data (in ppm) of Cphpd and its diamagnetic metal complexes

\begin{tabular}{lllll}
\hline Compounds & $\delta \mathrm{H} ;-\mathrm{CH}$ aliphatic (methyl) & $\delta \mathrm{H} ; \mathrm{H}_{2} \mathrm{O}$ & $\delta \mathrm{H} ;-\mathrm{CH}$ aromatic & $\delta \mathrm{H} ;-\mathrm{NH}$ hydrazid \\
\hline Cphpd & 2.42 & - & $6.81-7.23$ & 13.24 \\
$\mathrm{Pt}(\mathrm{IV}) /$ Cphpd & $2.08-2.58$ & 3.51 & $7.19-7.86$ & 14.53 \\
Ce(IV) / Cphpd & $2.44-2.51$ & 3.46 & $7.20-7.88$ & 14.53 \\
$\mathrm{U}(\mathrm{VI}) /$ Cphpd & $2.07-2.57$ & $3.24-3.37$ & $7.20-7.87$ & 14.54 \\
\hline
\end{tabular}


Table 4. Thermogravimetric data of Cphpd and its metal complexes

\begin{tabular}{|c|c|c|c|c|c|}
\hline \multirow{2}{*}{ Compounds } & \multirow{2}{*}{ Decomposition } & \multirow{2}{*}{$\mathrm{DTG}_{\max }\left({ }^{\circ} \mathrm{C}\right)$} & \multicolumn{2}{|c|}{ \% Estimated (calculated) } & \multirow{2}{*}{$\begin{array}{l}\text { Assignment } \\
\text { Lost species }\end{array}$} \\
\hline & & & Mass loss & Total mass loss & \\
\hline $\begin{array}{l}\text { Cphpd } \\
238.50, \mathrm{C}_{11} \mathrm{H}_{11} \mathrm{~N}_{2} \mathrm{O}_{2} \mathrm{Cl}\end{array}$ & $\begin{array}{l}\text { First step } \\
\text { Residue }\end{array}$ & 205 & $\begin{array}{l}59.54(59.75) \\
40.46(40.25)\end{array}$ & $59.54(59.75)$ & $\begin{array}{l}\mathrm{CH}_{4}+2 \mathrm{CO}+\mathrm{NH}_{4} \mathrm{Cl}+\mathrm{NH}_{3} \\
8 \mathrm{C}\end{array}$ \\
\hline $\begin{array}{l}{\left[\mathrm{VO}\left(\mathrm{C}_{11} \mathrm{H}_{11} \mathrm{~N}_{2} \mathrm{O}_{2} \mathrm{Cl}_{2}\right)_{2}\left(\mathrm{H}_{2} \mathrm{O}\right)\right] \mathrm{SO}_{4}} \\
658, \mathrm{VC}_{22} \mathrm{H}_{24} \mathrm{~N}_{4} \mathrm{O}_{10} \mathrm{Cl}_{2} \mathrm{~S}\end{array}$ & $\begin{array}{l}\text { First step } \\
\text { Residue }\end{array}$ & 228 & $\begin{array}{l}75.57(75.83) \\
24.43(24.15)\end{array}$ & $75.57(75.83)$ & $\begin{array}{l}10 \mathrm{C}_{2} \mathrm{H}_{2}+2 \mathrm{HCl}+4 \mathrm{NO}+\mathrm{CO}+\mathrm{H}_{2} \mathrm{O} \\
\mathrm{VSO}_{4}+\mathrm{C}\end{array}$ \\
\hline $\begin{array}{l}{\left[\mathrm{Pd}\left(\mathrm{C}_{11} \mathrm{H}_{11} \mathrm{~N}_{2} \mathrm{O}_{2} \mathrm{Cl}\right)_{2}\left(\mathrm{H}_{2} \mathrm{O}\right)_{2}\right] \mathrm{Cl}_{2} .2 \mathrm{H}_{2} \mathrm{O}} \\
726.42, \mathrm{PdC}_{22} \mathrm{H}_{30} \mathrm{~N}_{4} \mathrm{O}_{8} \mathrm{Cl}_{4}\end{array}$ & $\begin{array}{l}\text { First step } \\
\text { Second step } \\
\text { Residue }\end{array}$ & $\begin{array}{l}56 \\
205,466\end{array}$ & $\begin{array}{l}4.83(4.96) \\
61.54(61.67) \\
33.63(33.37)\end{array}$ & $66.37(66.63)$ & $\begin{array}{l}2 \mathrm{H}_{2} \mathrm{O} \\
6 \mathrm{C}_{2} \mathrm{H}_{2}+4 \mathrm{HCl}+2 \mathrm{NH}_{3}+\mathrm{NO}_{2}+\mathrm{NO}+2 \mathrm{H}_{2} \mathrm{O} \\
\mathrm{PdO}+10 \mathrm{C}\end{array}$ \\
\hline $\begin{array}{l}{\left[\mathrm{Pt}\left(\mathrm{C}_{11} \mathrm{H}_{11} \mathrm{~N}_{2} \mathrm{O}_{2} \mathrm{Cl}_{2} \mathrm{Cl}_{2}\right] \mathrm{Cl}_{2}\right.} \\
814.08, \mathrm{PtC}_{22} \mathrm{H}_{22} \mathrm{~N}_{4} \mathrm{O}_{4} \mathrm{Cl}_{6}\end{array}$ & $\begin{array}{l}\text { First step } \\
\text { Residue }\end{array}$ & 215 & $\begin{array}{l}66.37(66.21) \\
33.63(33.79)\end{array}$ & $66.37(66.21)$ & $\begin{array}{l}8 \mathrm{C}_{2} \mathrm{H}_{2}+2 \mathrm{CO}+6 \mathrm{HCl}+2 \mathrm{~N}_{2} \\
\mathrm{PtO}_{2}+4 \mathrm{C}\end{array}$ \\
\hline $\begin{array}{l}{\left[\mathrm{Ce}\left(\mathrm{C}_{11} \mathrm{H}_{11} \mathrm{~N}_{2} \mathrm{O}_{2} \mathrm{Cl}\right)_{2}\left(\mathrm{H}_{2} \mathrm{O}\right)_{2}\right]\left(\mathrm{SO}_{4}\right)_{2}} \\
845.12, \mathrm{CeC}_{22} \mathrm{H}_{26} \mathrm{~N}_{4} \mathrm{O}_{14} \mathrm{Cl}_{2} \mathrm{~S}_{2}\end{array}$ & $\begin{array}{l}\text { First step } \\
\text { Residue }\end{array}$ & 211,498 & $\begin{array}{l}56.69(56.44) \\
43.31(43.55)\end{array}$ & $56.69(56.44)$ & $\begin{array}{l}9 \mathrm{C}_{2} \mathrm{H}_{2}+\mathrm{CO}_{2}+2 \mathrm{NO}_{2}+3 \mathrm{NH}_{4} \mathrm{Cl} \\
\mathrm{Ce}\left(\mathrm{SO}_{4}\right)_{2}+3 \mathrm{C}\end{array}$ \\
\hline $\begin{array}{l}{\left[\mathrm{UO}_{2}\left(\mathrm{C}_{11} \mathrm{H}_{11} \mathrm{~N}_{2} \mathrm{O}_{2} \mathrm{Cl}\right)_{2}\right]\left(\mathrm{NO}_{3}\right)_{2} .3 \mathrm{H}_{2} \mathrm{O}} \\
925.03, \mathrm{UC}_{22} \mathrm{H}_{28} \mathrm{~N}_{6} \mathrm{O}_{15} \mathrm{Cl}_{2}\end{array}$ & $\begin{array}{l}\text { First step } \\
\text { Second step } \\
\text { Residue }\end{array}$ & $\begin{array}{l}81 \\
198,490\end{array}$ & $\begin{array}{l}5.62(5.83) \\
56.03(55.89) \\
38.35(38.27)\end{array}$ & $61.65(61.72)$ & $\begin{array}{l}3 \mathrm{H}_{2} \mathrm{O} \\
7 \mathrm{C}_{2} \mathrm{H}_{2}+\mathrm{CO}_{2}+4 \mathrm{NO}_{2}+2 \mathrm{NH}_{4} \mathrm{Cl} \\
\mathrm{UO}_{2}+7 \mathrm{C}\end{array}$ \\
\hline
\end{tabular}

The thermal decompostion of $\left[\mathrm{VO}(\mathrm{Cphpd})_{2}\left(\mathrm{H}_{2} \mathrm{O}\right)\right] \mathrm{SO}_{4}$ complex proceeds with one degradation step. The decomposition stage occurs at one maximum temperature at $228^{\circ} \mathrm{C}$ with intermediate formation of very unstable products which were not identified and the weight loss found at this stage equals to $75.57 \%$ corresponds to loss $10 \mathrm{C}_{2} \mathrm{H}_{2}+2 \mathrm{HCl}+4 \mathrm{NO}$ $+\mathrm{CO}+\mathrm{H}_{2} \mathrm{O}$.

For Pd(II) complex, the thermal decomposition exhibits two main degradation steps. The first step involves decomposition in which the complex losses water molecules of crystalization. The second step of decompostion occurs at two maxima 205 and $466{ }^{\circ} \mathrm{C}$ with a weight loss of $61.54 \%$ associated with the loss of Cphpd and two coordinated water molecules, leaving palladium oxide as residue.

The thermal degradation exhibits one step with maximum temperature at $215^{\circ} \mathrm{C}$ for $\left[\mathrm{Pt}(\mathrm{Cphpd})_{2} \mathrm{Cl}_{2}\right] \mathrm{Cl}_{2}$ and two maxima at 211 and $498{ }^{\circ} \mathrm{C}$ for $\left[\mathrm{Ce}(\mathrm{Cphpd})_{2}\left(\mathrm{H}_{2} \mathrm{O}\right)_{2}\right]\left(\mathrm{SO}_{4}\right)_{2}$ with a weight loss of $8 \mathrm{C}_{2} \mathrm{H}_{2}+2 \mathrm{CO}+6 \mathrm{HCl}+2 \mathrm{~N}_{2}(66.37 \%)$ and $9 \mathrm{C}_{2} \mathrm{H}_{2}$ $+\mathrm{CO}_{2}+2 \mathrm{NO}_{2}+3 \mathrm{NH}_{4} \mathrm{Cl}(56.69 \%)$, giving $\mathrm{PtO}_{2}$ and $\mathrm{Ce}\left(\mathrm{SO}_{4}\right)_{2}$ as a final product.

For U(VI) complex, the thermal decomposition exhibits two main degradation steps. The first step occurring from 35 to $85^{\circ} \mathrm{C}$ is accompanied by a weight loss of $5.62 \%$ in agreement with the theoretical values $5.83 \%$ for the loss of three uncoordinated water molecules. The second stage occurs at two maxima temperatures 198 and $490^{\circ} \mathrm{C}$ corresponding to the loss of $\mathrm{Cphpd}$ forming uranium oxide as a final product (Table 4).

\section{Biological Activities}

The susceptibility of certain strains of bacterium, such as S. aureus K1, B. subtilis K22, E. Coli K32 and P. aerug- inosa SW1 and antifungal screening was studied against two species, aspergillus flarus (A. flarus) and aspergillus fumigates (A. fumigates) towards Cphpd and its complexes, and judged by measuring size of the inhibitions diameter (Table 5). The results of the antibacterial study of Cphpd and the five metal complexes have inhibitory action against all four types of bacteria and no antifungal activity observed for ligand and their metal complexes. The complex of V(IV) showed a significant difference against all four types of bacteria than free ligand. The Pd(II) complex showed significant for Gram-negative and highly significant for Grampositive bacteria. $\mathrm{Pt}(\mathrm{IV})$ showed highly significant difference against $E$. Coli $\mathrm{K} 32$, significant difference against $S$. aureus $\mathrm{K} 1$ and not significant against $B$. subtilis $\mathrm{K} 22$ and $P$. aeruginosa SW1. The Ce(IV) showed highly significant against Gram-positive and not significant against Gram-negative bacteria. U(VI) showed highly significant difference against $S$. aureus $\mathrm{K} 1$, significant difference against E. Coli $\mathrm{K} 32$ and B. subtilis (Table 5). The results are promising compared with the previous studies..$^{21,22}$ Such increased activity of metal chelate can be explained on the basis of the oxidation state of the metal ion, overtone concept and chelation theory. According to the overtone concept of cell permeability, the lipid membrane that surrounds the cell favors the passage of only lipid-soluble materials in which liposolubility is an important factor that controls the antimicrobial activity. On chelation the polarity of the metal ion will be reduced to a greater extent due to overlap of ligand orbital and partial sharing of the positive charge of the metal ion with donor groups. Further it increases the delocalization of $\pi$-electrons over the whole chelate ring and enhances the lipophilicity of the complexes. ${ }^{23}$ This increased 
Table 5. The inhibitation diameter zone values $(\mathrm{mm})$ for Cphpd and their complexes

\begin{tabular}{|c|c|c|c|c|c|c|c|}
\hline \multirow{3}{*}{\multicolumn{2}{|c|}{ Compounds }} & \multicolumn{6}{|c|}{ Microbial species } \\
\hline & & \multicolumn{4}{|c|}{ Bacteria } & \multicolumn{2}{|c|}{ fungi } \\
\hline & & E. coli & P. aeruginosa & B. subtilis & S. aureus & A. flarus & A. Fumigates \\
\hline \multicolumn{2}{|l|}{ Cphpd } & $10 \pm 0.33$ & $15 \pm 0.11$ & $20 \pm 0.22$ & $23 \pm 0.90$ & 0 & 0 \\
\hline \multicolumn{2}{|c|}{ Cphpd / V(IV) } & $20^{+1} \pm 0.22$ & $24^{+1} \pm 0.02$ & $26^{+1} \pm 0.44$ & $28^{+1} \pm 0.06$ & 0 & 0 \\
\hline \multicolumn{2}{|c|}{ Cphpd / Pd(II) } & $21^{+1} \pm 0.11$ & $25^{+1} \pm 0.03$ & $35^{+2} \pm 0.30$ & $38^{+2} \pm 0.88$ & 0 & 0 \\
\hline \multicolumn{2}{|c|}{ Cphpd / Pt(IV) } & $25^{+2} \pm 0.22$ & $18^{\mathrm{NS}_{ \pm 0.04}}$ & $22^{\mathrm{NS}} \pm 0.20$ & $28^{+1} \pm 0.33$ & 0 & 0 \\
\hline \multicolumn{2}{|c|}{ Cphpd / Ce(IV) } & $14^{\mathrm{NS}_{ \pm 0.15}}$ & $16^{\mathrm{NS}_{ \pm} 0.05}$ & $30^{+2} \pm 0.13$ & $40^{+2} \pm 0.11$ & 0 & 0 \\
\hline \multicolumn{2}{|c|}{ Cphpd / U(VI) } & $18^{+1} \pm 0.12$ & 0 & $25^{+1} \pm 0.60$ & $39^{+2} \pm 0.14$ & 0 & 0 \\
\hline \multicolumn{2}{|c|}{$\mathrm{VO}\left(\mathrm{SO}_{4}\right)_{2} \cdot 2 \mathrm{H}_{2} \mathrm{O}$} & 0 & 0 & 0 & 0 & 0 & 0 \\
\hline \multicolumn{2}{|c|}{$\mathrm{PdCl}_{2}$} & $9 \pm 0.73$ & 0 & $5 \pm 0.53$ & 0 & 0 & 0 \\
\hline \multicolumn{2}{|l|}{$\mathrm{PtCl}_{4}$} & 0 & 0 & 0 & 0 & 0 & 0 \\
\hline \multicolumn{2}{|l|}{$\mathrm{Ce}\left(\mathrm{SO}_{4}\right)_{2}$} & 0 & 0 & 0 & 0 & 0 & 0 \\
\hline \multicolumn{2}{|c|}{$\mathrm{UO}_{2}\left(\mathrm{NO}_{3}\right)_{2} \cdot 6 \mathrm{H}_{2} \mathrm{O}$} & 0 & 0 & 0 & 0 & 0 & 0 \\
\hline \multicolumn{2}{|c|}{ Control (DMSO) } & 0 & 0 & 0 & 0 & 0 & 0 \\
\hline \multirow{3}{*}{ Standard } & Ampicilin & 0 & 13 & 28 & 18 & 0 & 0 \\
\hline & Amoxycillin & 0 & 23 & 22 & 16 & 0 & 0 \\
\hline & Cefaloxin & 24 & 0 & 27 & 0 & 0 & 0 \\
\hline
\end{tabular}

Statistical significance $\mathrm{P}^{\mathrm{NS}}-\mathrm{P}$ not significant, $\mathrm{P}>0.05 ; \mathrm{P}^{+1}-\mathrm{P}$ significant, $\mathrm{P}<0.05 ; \mathrm{P}^{+2}-\mathrm{P}$ highly significant, $\mathrm{P}<0.01 ; \mathrm{P}^{+3}-\mathrm{P}$ very highly significant, $\mathrm{P}>0.001$; Student's t-test (Paired).

lipophilicity enhances the penetration of complexes into the lipid membranes and blocks the metal binding sites in enzymes of microorganisms. These complexes also disturb the respiration process of the cell and thus block the synthesis of proteins, which restricts further growth of the microorganisms.

\section{COMPUTATIONAL DETAILS}

\section{Computational Method}

The geometric parameters and energies were computed by density functional theory at the B3LYP/CEP-31G level of theory, using the GAUSSIAN $98 \mathrm{~W}$ package of the programs, on geometries that were optimized at CEP-31G basis set. The high basis set was chosen to detect the energies at a highly accurate level. The atomic charges were computed using the natural atomic orbital populations. The B3LYP is the keyword for the hybrid functional, ${ }^{24}$ which is a linear combination of the gradient functionals proposed by Becke ${ }^{25}$ and Lee, Yang and Parr, ${ }^{26}$ together with the Hartree-Fock local exchange function. ${ }^{27}$

\section{Structural Parameters and Model of Ligand Cphpd}

The biological activity of Cphpd is mainly determined by its fine structure, the Cphpd has many characteristic structural features. The antimicrobial activity of the synthesized Cphpd might be attributed to interferance with nutrient transporter on plasma membrane as $\mathrm{ABC}$ transporter, or changing the ionic state by free chlorine/metal interaction with membrane poreins/interference with membrane lipids. As well as, the reliable cytotoxic effect reasons, might be due to the interaction with various metallo-enzymes especially with mitochondrial enzymes..$^{28}$ Table 6 gives the optimized geometry of Cphpd as obtained from B3LYP/CEP-31G calculations. The values of bond distances are compared nicely with that obtained from X-ray data. ${ }^{29}$ The molecule is not highly sterically-hindered, the two benzene ring in the same plane of the all fragments. This observation is supported by the values of calculated dihedral angles. Scheme 3, showed the opti-

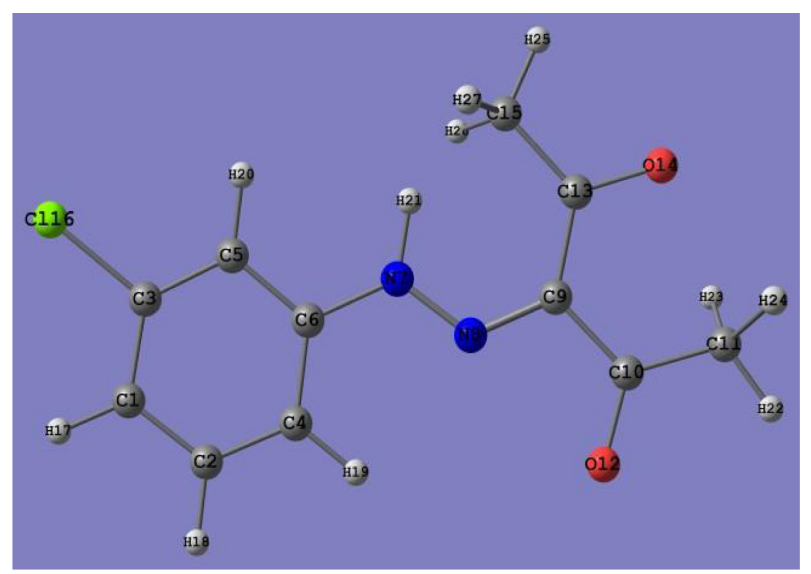

Scheme 3. Optimized geometrical structure of Cphpd by using B3LYP/CEP-31G. 
Table 6. Equilibrium geometric parameters bond lengths $(\AA)$, bond angles $\left({ }^{\circ}\right)$, dihedral angles $\left({ }^{\circ}\right)$ and charge density of Cphpd ligand by using DFT/B3LYP/CEP-31G.

\begin{tabular}{|c|c|c|c|}
\hline \multicolumn{4}{|l|}{ Bond length $(\AA)$} \\
\hline$\overline{\mathrm{C} 13-\mathrm{O} 14}$ & $1.285(1.30)$ & $\mathrm{C} 10-\mathrm{O} 12$ & $1.285(1.30)$ \\
\hline C10-C11 & 1.463 & $\mathrm{C} 13-\mathrm{C} 15$ & 1.469 \\
\hline C9-C10 & $1.452(1.41)$ & C9-N8 & 1.334 \\
\hline C6-N7 & 1.406 & $\mathrm{C} 2-\mathrm{C} 4$ & $1.392(1.38)$ \\
\hline $\mathrm{C} 3-\mathrm{Cl}$ & 1.737 & $\mathrm{C} 1-\mathrm{C} 2$ & 1.395 \\
\hline $\mathrm{C} 5-\mathrm{C} 6$ & 1.401 & $\mathrm{C} 5-\mathrm{C} 6$ & 1.401 \\
\hline $\mathrm{C} 3-\mathrm{C} 5$ & 1.388 & $\mathrm{C} 1-\mathrm{C} 3$ & 1.389 \\
\hline \multirow[t]{2}{*}{$\mathrm{N} 7-\mathrm{N} 8$} & 1.304 & $\mathrm{C} 4-\mathrm{C} 6$ & 1.402 \\
\hline & & C9-C13 & 1.449 \\
\hline \multicolumn{4}{|l|}{ Bond angle $\left({ }^{\circ}\right)$} \\
\hline C6N7N8 & 121.22 & C9C13O14 & 117.69 \\
\hline N7N8C9 & 121.83 & $\mathrm{C} 9 \mathrm{C} 13 \mathrm{Cl} 5$ & 124.06 \\
\hline $\mathrm{C} 15 \mathrm{C} 13 \mathrm{O} 14$ & 118.25 & C9C10C11 & 119.07 \\
\hline N8C9C10 & 112.82 & $\mathrm{C} 11 \mathrm{C} 10 \mathrm{O} 12$ & 120.58 \\
\hline N8C9C13 & 124.41 & & \\
\hline \multicolumn{4}{|l|}{ Dihedral angles $\left({ }^{\circ}\right)$} \\
\hline C5C6N7N8 & -180.00 & N8C9C10O12 & 0.00 \\
\hline N8C9C13O14 & -180.00 & N8C9C10C11 & 180.00 \\
\hline N8C9C13C15 & 0.00 & & \\
\hline \multicolumn{4}{|l|}{ Charges } \\
\hline $\mathrm{N} 8$ & -0.143 & O14 & -0.372 \\
\hline $\mathrm{C} 10$ & 0.323 & C9 & -0.09 \\
\hline $\mathrm{C} 13$ & 0.302 & $\mathrm{O} 12$ & -0.386 \\
\hline N7 & -0.013 & $\mathrm{C} 15$ & -0.215 \\
\hline $\mathrm{C} 11$ & -0.212 & & \\
\hline \multicolumn{2}{|l|}{ Total energy/au } & -149.1178 & \\
\hline \multicolumn{2}{|l|}{ Total dipole moment/D } & 3.023 & \\
\hline
\end{tabular}

mized geometrical structure of Cphpd molecule. The dihedral angles confirm $\mathrm{C} 10 \mathrm{O} 12$ group is lying in cis form with respect to $\mathrm{C} 9 \mathrm{~N} 8$ group and $\mathrm{C} 13 \mathrm{O} 14$ group in trans form with respect to C9N8 group. The chelation of this ligand can be occurred through the nitrogen atom of hydrazono group N8 and the oxygen atom of keto group $\mathrm{O} 12$ as bi-dentate ligand.

Charge distribution on the optimized geometry of Cphpd is given in Table 6. There is a significant built up of charge density on the oxygen atoms of the two keto groups and nitrogen atom of hydrazono group so we expect that Cphpd ligand behave as bi-dentate ( $\mathrm{O}_{\text {keto }}$ and $\mathrm{N}_{\text {hyd }}$ atoms $)$ and the molecule is not highly dipole $\mu=3.023$ because the planarity of the Cphpd molecule, the charges accumulated on $\mathrm{O} 12$ and $\mathrm{O} 14$ are -0.386 and -0.372 , respectively, also, the charges on $\mathrm{N}_{8}$ and $\mathrm{N}_{7}$ are -0.143 and 0.013 , respectively. These values of charges enhance the chelation through the $\mathrm{O} 12$ of keto group and the N8 of the hydrazono group. The value of energy of the optimized geometry is $-149.117 \mathrm{au}$.

\section{Proposal Structure of the Complexes with Molecular Modeling}

Description of the structure of $\left[\mathrm{VO}(\mathrm{Cphpd})_{2}\left(\mathrm{H}_{2} \mathrm{O}\right)\right]^{2+}$

The V(IV) may be chelated with two molecules of Cphpd through four coordinate bonds $\left(\mathrm{O}_{\text {keto }}\right.$ and $\mathrm{N}_{\text {hyd }}$ atoms) from each molecule. The experimental data set that the result complex is six-coordinate so, the complex consists of four coordinate bonds with two Cphpd molecules and coordinated bond with water molecule beside oxygen atom of V(IV) ion. In this part we study theoretically the structure parameters of $\left[\mathrm{VO}(\mathrm{Cphpd})_{2}\left(\mathrm{H}_{2} \mathrm{O}\right)\right]^{2+}$ complex. The energy of the isomers is almost equal as expected, ${ }^{30}$ it is difficult to distinguish between trans and cis isomers. Nevertheless, the trans Oc-isomer exhibit the lowest energy.

The structure of complex with atomic numbering scheme is shown in Scheme 4. The complex consists of two units of Cphpd molecule and one water molecule with VO ion. The complex is six-coordinate with distorted octahedral environment around the metal ion. The bond lengths and angles were calculated and found in Table 7. These values agree with these expected for a distorted octahedron. ${ }^{31-36}$ The two Cphpd molecules are perpendicular to each other and they are not lying in the same plane.

The energy of this complex is -338.096 au and the dipole moment is high (17.865D) and the charges accumulated on $\mathrm{O}_{\text {keto }}$ are -0.274 and -0.255 and on $\mathrm{N}_{\text {hyd }}$ are 0.04 and 0.019 , in octahedral complex. There is a strong interaction between central metal ion V(IV) which has charge equal +0.578 and Cphpd molecule which more negative oxygen and nitrogen atoms in octahedral complex. For this reason the octahedral complex is more stable.

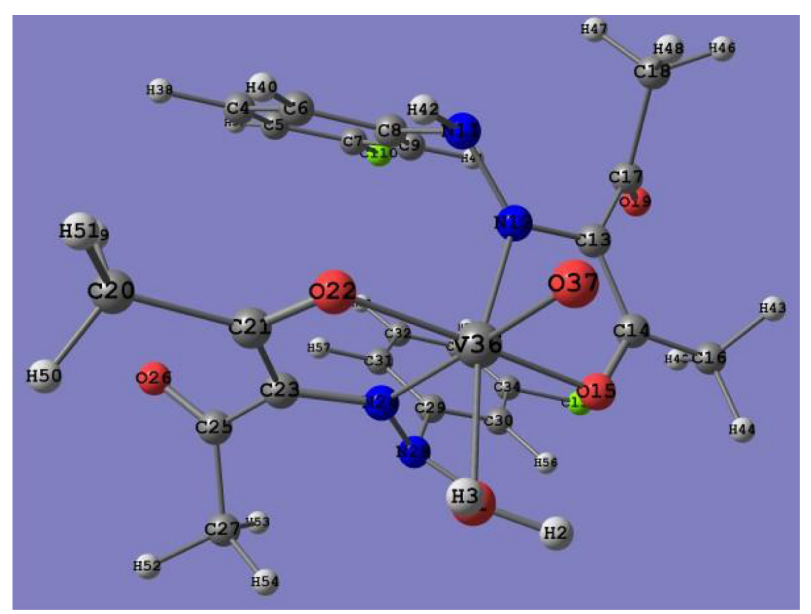

Scheme 4. Optimized geometrical structure of trans Oc-isomer of $\left[\mathrm{VO}(\mathrm{Cphpd})_{2}\left(\mathrm{H}_{2} \mathrm{O}\right)\right]^{2+}$ complex by using B3LYP/CEP-31G. 
Table 7. Equilibrium geometric parameters bond lengths $(\AA)$, bond angles $\left({ }^{\circ}\right)$ and charge density of $\left[\mathrm{VO}(\mathrm{Cphpd})_{2}\left(\mathrm{H}_{2} \mathrm{O}\right)\right]^{2+}$ complex by using B3LYP/CEP-31G

\begin{tabular}{|c|c|c|c|}
\hline \multicolumn{4}{|c|}{ Bond length $(\AA)$} \\
\hline $\mathrm{V}-\mathrm{O} 15$ & 1.869 & C13-N12 & 1.349 \\
\hline $\mathrm{V}-\mathrm{O} 22$ & 1.868 & $\mathrm{C} 44-\mathrm{O} 15$ & 1.215 \\
\hline $\mathrm{V}-\mathrm{N} 12$ & 1.914 & $\mathrm{C} 23-\mathrm{N} 24$ & 1.348 \\
\hline $\mathrm{V}-\mathrm{N} 24$ & 1.912 & $\mathrm{C} 21-\mathrm{O} 22$ & 1.215 \\
\hline $\mathrm{V}-\mathrm{O} 37$ & 1.789 & C13-C14 & 1.364 \\
\hline $\mathrm{V}-\mathrm{O}_{\mathrm{H} 2 \mathrm{O}}$ & 1.899 & $\mathrm{C} 21-\mathrm{C} 23$ & 1.364 \\
\hline \multicolumn{4}{|c|}{ Bond angle $\left({ }^{\circ}\right)$} \\
\hline O37 V O15 & 92.72 & O15 V O1 & 88.37 \\
\hline O37 V N12 & 88.13 & O15 V O37 & 92.72 \\
\hline O37 V N24 & 166.19 & N12 V N24 & 102.39 \\
\hline O37 V O22 & 88.92 & $\mathrm{~N} 12 \mathrm{~V} \mathrm{O} 22$ & 100.18 \\
\hline O37 V O1 & 86.53 & N12 V O1 & 167.31 \\
\hline O15 V N12 & 80.39 & $\mathrm{~N} 24 \mathrm{~V} \mathrm{O} 22$ & 80.49 \\
\hline O15 V N24 & 97.81 & N24 V O1 & 84.86 \\
\hline \multirow[t]{2}{*}{$\mathrm{O} 15 \mathrm{~V} \mathrm{O} 22$} & 178.29 & O22 V O1 & 91.23 \\
\hline & & $\mathrm{O} 22 \mathrm{~V} \mathrm{O} 37$ & 88.92 \\
\hline \multicolumn{4}{|l|}{ Charges } \\
\hline V & 0.578 & $\mathrm{C} 21$ & 0.381 \\
\hline $\mathrm{O} 15$ & -0.274 & $\mathrm{C} 23$ & 0.012 \\
\hline N12 & 0.040 & $\mathrm{O} 37$ & -0.281 \\
\hline $\mathrm{C} 13$ & 0.019 & O1 & -0.322 \\
\hline \multirow[t]{2}{*}{$\mathrm{N} 24$} & 0.006 & $\mathrm{C} 14$ & 0.419 \\
\hline & & $\mathrm{O} 22$ & -0.255 \\
\hline \multicolumn{2}{|c|}{ Total energy/au } & -338.096 & \\
\hline \multicolumn{2}{|c|}{ Total dipole moment/D } & 17.856 & \\
\hline
\end{tabular}

\section{Description of the structure of $\left[\mathrm{Pd}(\mathrm{Cphpd})_{2}\left(\mathrm{H}_{2} \mathrm{O}\right)_{2}\right]^{2+}$}

Scheme 5 shows the optimized geometrical structure of $\left[\mathrm{Pd}(\mathrm{Cphpd})_{2}\left(\mathrm{H}_{2} \mathrm{O}\right)_{2}\right]^{2+}$ with the atomic numbering scheme. The selected bond distances and angles are given in Table 8.

The Pd(II) ion, at a crystallographic inversion center, is in a distorted octahedral environment. The metal ion may be coordinated by two oxygen atoms $\left(\mathrm{O}_{\text {keto }}\right)$ and two nitrogen atoms $\left(\mathrm{N}_{\mathrm{hyd}}\right)$ of two Cphpd ligand beside two oxygen atoms of two water molecules to complete the octahedral structure. $^{37-46}$

In the equatorial plane the $\mathrm{Pd}(\mathrm{II})$ bonded with one oxygen atom and one nitrogen atom (O18 and N15) of Cphpd molecule beside two oxygen atoms, one oxygen atom $(\mathrm{O} 25)$ of other ligand molecule and one oxygen atom $(\mathrm{O} 4)$ of water molecule. These four atoms are lying in the same plane which perpendicular to the other plane occupied by other atoms (N27) of other ligand molecule and $\mathrm{O} 1$ of other water molecule. The bond angles O18PdO25 and O18PdN27 are 93.48 and 96.75 . The bond angles $\mathrm{N} 15 \mathrm{PdO} 25$ and O18PdO4 are 166.32and 170.52, also, the bond angle O1PdN27 is 159.51 . These values confirm that the two ligand molecules not occupy the same plane but they are perpendicular to

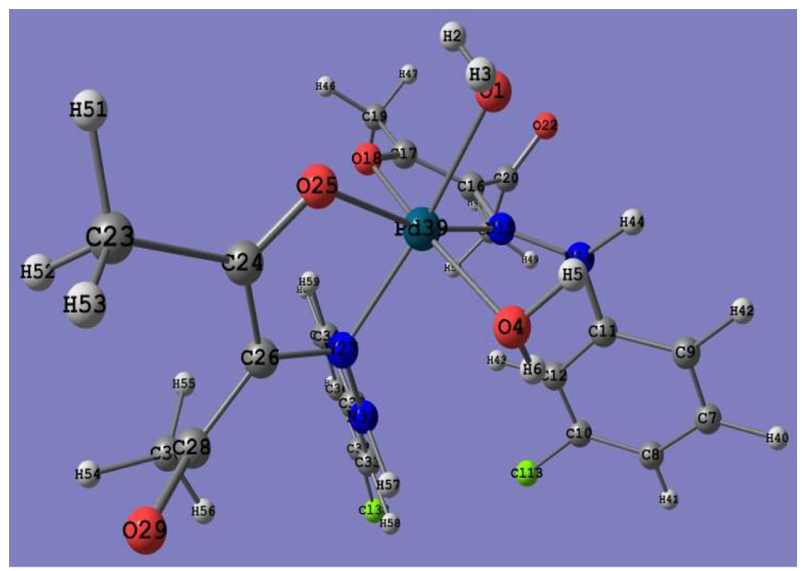

Scheme 5. Optimized geometrical structure of trans O-isomer of $\left[\mathrm{Pd}(\mathrm{Cphpd})_{2}\left(\mathrm{H}_{2} \mathrm{O}\right)_{2}\right]^{2+}$ complex by using B3LYP/CEP-31G.

Table 8. Equilibrium geometric parameters bond lengths $(\AA)$, bond angles $\left({ }^{\circ}\right)$ and charge density of $\left[\mathrm{Pd}(\mathrm{Cphpd})_{2}\left(\mathrm{H}_{2} \mathrm{O}\right)_{2}\right]^{2+}$ by using DFT/B3LYP/CEP-31G

\begin{tabular}{|c|c|c|c|}
\hline \multicolumn{4}{|c|}{ Bond length $(\AA)$} \\
\hline Pd-O18 & 1.923 & $\mathrm{Pd}-\mathrm{O} 4$ & 1.951 \\
\hline $\mathrm{Pd}-\mathrm{O} 25$ & 1.924 & $\mathrm{C} 17-\mathrm{O} 18$ & 1.216 \\
\hline $\mathrm{Pd}-\mathrm{N} 15$ & 1.967 & $\mathrm{C} 16-\mathrm{C} 17$ & 1.363 \\
\hline $\mathrm{Pd}-\mathrm{N} 27$ & 1.971 & C16-N15 & 1.348 \\
\hline $\mathrm{Pd}-\mathrm{O} 1$ & 1.953 & $\mathrm{C} 24-\mathrm{O} 25$ & 1.214 \\
\hline C26-N27 & 1.349 & $\mathrm{C} 24-\mathrm{C} 26$ & 1.364 \\
\hline \multicolumn{4}{|c|}{ Bond angle $\left({ }^{\circ}\right)$} \\
\hline O1 Pd N15 & 86.49 & \multicolumn{2}{|c|}{ O18 Pd N27 N27 96.75} \\
\hline O1 Pd O25 & 82.49 & $\mathrm{Pd} \mathrm{O} 25 \mathrm{O} 1 \mathrm{Pd}$ & 79.08 \\
\hline N15 Pd N27 & 112.95 & O18 & 93.21 \\
\hline N15 Pd O25 & 166.32 & O1 Pd O4 & 87.26 \\
\hline O18 Pd O25 & 93.48 & N27 Pd O4 & 85.85 \\
\hline N15 Pd O4 & 91.56 & O1 Pd N27 & 159.51 \\
\hline O18 Pd O4 & 170.52 & N15 Pd O18 & 79.03 \\
\hline $\mathrm{O} 25 \mathrm{Pd} \mathrm{O} 4$ & 95.96 & & \\
\hline \multicolumn{4}{|l|}{ Charges } \\
\hline $\mathrm{Pd}$ & 0.688 & $\mathrm{C} 17$ & 0.401 \\
\hline $\mathrm{C} 16$ & 0.131 & $\mathrm{C} 24$ & 0.402 \\
\hline N27 & 0.559 & $\mathrm{O} 4$ & -0.395 \\
\hline $\mathrm{O} 1$ & -0.399 & $\mathrm{O} 18$ & -0.568 \\
\hline \multirow[t]{2}{*}{ N15 } & 0.689 & $\mathrm{O} 25$ & -0.660 \\
\hline & & $\mathrm{C} 26$ & 0.137 \\
\hline \multicolumn{2}{|c|}{ Total energy/au } & \multicolumn{2}{|l|}{-363.135} \\
\hline \multicolumn{2}{|c|}{ Total dipole moment/D } & \multicolumn{2}{|l|}{8.097} \\
\hline
\end{tabular}

each other. The energy of this complex is -363.135 au and the dipole moment is high $8.097 \mathrm{D}$, so this complex is more stable.

The bond distances between Pd(II) and surrounded oxygen atoms and nitrogen atoms of Cphpd in complex are shown in Table 8. Also, the charges accumulated on $\mathrm{O}_{\text {keto }}$ are -0.568 and -0.660 and on $\mathrm{N}_{\text {hyd }}$ are 0.689 and 0.559 . There is a strong interaction between central metal ion $\mathrm{Pd}(\mathrm{II})$ 
which has charge equal +0.688 and more negative oxygen and nitrogen atoms in octahedral complex. For this reason the octahedral complex is more stable and $\mathrm{Pd}(\mathrm{II})$ favor coordinated with two molecules of Cphpd with four coordinated bonds and completes the octahedron structure by bonding with two water molecules.

\section{CONCLUSION}

The reaction of some transition metal ions V(IV), $\mathrm{Pd}(\mathrm{II})$, $\mathrm{Pt}(\mathrm{IV}), \mathrm{Ce}(\mathrm{IV})$ and U(VI) with Cphpd has been studied. The results of the elemental analysis and thermogravimetric analysis deduced the formation of $2: 1 \mathrm{Cphpd} / \mathrm{metal}$ ions complexes in all cases. The structure of the formed complexes were further supported by infrared, UV-vis and ${ }^{1} \mathrm{H}$ NMR spectra. The Cphpd has two donating centers $\mathrm{O}_{\text {keto }}$ and $\mathrm{N}_{\text {hyd }}$ when chelated with metal ions and the metal ions completed the octahedral structures with water molecules or chloride ions, there are six-coordinated bonds are formed four with two Cphpd molecules and other two with two water molecules or chloride ions. The produced complexes are treated as distorted octahedral complex. For all studied complexes the two Cphpd molecules are perpendicular to each other and they are not lying in the same plane. In case of V(IV) in VO ion the energy difference between two enantiomers cis and trans is very low, it is difficult to distinguish between trans or cis isomers. Nevertheless, the trans-isomer exhibits the lowest energy value. Antimicrobial studies were carried out against $S$. aureus $\mathrm{K} 1$, B. subtilis $\mathrm{K} 22$, E. coli $\mathrm{K} 32$ and $P$. aeruginosa $\mathrm{SW} 1$ and antifungal screening was studied. The results showed significant increase in antibacterial activity of metal complexes as compared with uncomplexed ligand and no antifungal activity observed for ligand and their complexes.

Acknowledgments. The author would like to thank the colleagues at University of Zagazig, Faculty of Science, Microbiology and Chemistry Department for performing the antimicrobial measurements (Prof. Dr. Ashraf sabry and Dr.Walaa H. El-Shwiniy). And the publication cost of this paper was supported by the Korean Chemical Society.

\section{REFERENCES}

1. Odabasoglu, M.; Büyükgüngör, O.; Sarojini, B. K.; Narayana, B. Acta Cryst. 2007, E63, o4135.

2. Rashad, A. E.; Shamroukh, A. H.; El-Hashash, M. A.; El-Farargy, A. F.; Yousif, N. M.; Salama, M. A.; Mostafa, A.; El-Shahat, M. J. Heterocyclic. Chem. 2012, 49, 1130.
3. Zordok, W. A.; Sadeek, S. A.; EL-Shwiniy, W. H. J. Coord. Chem. 2012, 65, 353.

4. Beecher, D. J.; Wong, A. C. Appl. Environ. Microbial. 1994, 60, 1646.

5. Geary, W. J. Coord. Chem. Rev. 1971, 7, 81.

6. Nour, E. M.; Alnami, I. S.; Alem, N. A. J. Phys. Chem. Solids 1992, 53, 197.

7. Mcglynnm, S. P.; Smith, J. K.; Neely, W. C. J. Chem. Phys. 1961, 35, 105.

8. Syamal, A.; Singhal, P. O.; Banerjee, S. Synth. React. Inorg. Met.-Org. Chem. 1980, 243, 10.

9. Jones, L. H. Spectrochim. Acta 1958, 10, 395; Jones, L. H. Spectrochim. Acta 1959, 11, 409.

10. Nakamoto, K. Infrared and Raman Spectra of Inorganic and Coordination Compounds, 4th ed.; Wiley: New York, 1986, pp 230-233.

11. Sultana, N.; Arayne, M. S.; Gul, S.; Shamim, S. J. Mol. Struct. 2010, 975, 285.

12. Zordok, W. A.; El-Shwiniy, W. H.; El-Attar, M. S.; Sadeek, S. A. J. Mol. Struct. 2013, 1047, 267.

13. King, D. E.; Malone, R.; Lilley, S. H. Am. Fam. Phys. 2000, $61,2741$.

14. Patai, S. Chemistry of the Carbon-nitrogen Double Bond; Willey: New York, 1970; pp 238-247.

15. Jones, L. H. Spectrochim. Acta 1959, 15, 409.

16. Sadeek, S. A.; Teleb, S. M.; AL-Kority, A. M. J. Indian Chem. Soc. 1993, 70, 63.

17. Refat, M. S. Spectrochim. Acta., Part A 2007, 68, 1393.

18. Nakamoto, K.; McCarthy, P. J.; Spectroscopy and Structure of Metal Chelate Compounds; John Wiley \& Sons: New York, London, Sydney, 1968; chapter 2.

19. Saif, M.; Mashaly, M. M.; Eid, M. F.; Fouad, R. Spectrochim. Acta.; Part A 2012, 92, 347.

20. Skauge, T.; Turel, I.; Sletten, E. Inorg. Chem. Acta. 2002, 339, 239.

21. Rossmore, H. W. Disinfection, Sterilization and Preservation, 4th ed.; Block, S. S., Ed., Lea and Febiger: Philadelphia, 1991; pp 290-321.

22. Russell, A. D. Disinfection, Sterilization and Preservation, 4th ed.; Block, S. S., Ed., Lea and Febinger: Philadelphia, 1991, pp. 27-59.

23. Beltagi, A. M. J. Pharm. Biomed. Anal. 2003, 31, 1079.

24. Kohn, W.; Sham, L. J. Phys. Rev. A 1965, 140, 1133.

25. Becke, A. D. Phys. Rev. A 1988, 38, 3098.

26. Lee, C.; Yang, W.; Parr, R. G. Phys. Rev. B 1988, 37.

27. Flurry, R. L. Jr. Molecular Orbital Theory of Bonding in Organic Molecules; Marcel Dekker: New York, 1968.

28. Warrilow, A. G. S.; Martel, C. M.; Parker, J. E.; Melo, N.; Lamb, D. C.; Nes, W. D.; Kelly, D. E.; Kelly, S. L. Antmicrob. Agents Chemother. 2010, 54, 4235.

29. Turel, I.; Golic, L.; Bukovec, P.; Gubina, M. J. Inorg. Biochem. 1998, 71, 53.

30. Ahmed, M.; Schwendt, P.; Marek, J.; Sivak, M. Polyhedron 2004, 23, 655.

31. Grivani, G.; Khalaji, A. D.; Tahmasebi, V.; Gotoh, K.; Ishida, 
H. Polyhedron 2012, 31, 265.

32. Gonzalez-Baro, A. C.; Castellano, E. E.; Piro, O. E.; Parajon-Costa, B. S. Polyhedron 2005, 24, 49.

33. Kuriakose, M.; Prathapachandra Kurup, M. R.; Suresh, E. Polyhedron 2007, 26, 2713.

34. Vannan, M.; Lloffman, J. T.; Dimayuga, V. L.; Dwight, T.; Carrano, C. J. Inorg. Chem. Acta 2007, 360, 529.

35. Rochon, F. D.; Massarweh, G. Inorg. Chim. Acta 2006, 359, 4095.

36. Quintal, S. M. O.; Felix, V.; Drew, M. G. B.; Nogueira, H. I. S. Polyhedron 2006, 25, 753.

37. Hao, Y. Z.; Li, Z. X.; Tian, J. L. J. Mol. Catal. A.: Chem. 2007, 265, 258.

38. Kaplum, M.; Sandstrom, M.; Bostrom, D.; Shchukarev, A.; Persson, P. Inorg. Chem. Acta 2005, 358, 527.

39. López, C.; Caubet, A.; Perez, S.; Solans, X.; Font-Bardı,
M. J. Organ. Chem. 2003, 681, 82.

40. Kumar, P. R.; Upreti, S.; Singh, A. K. Polyhedron 2008, 27, 1610-1622.

41. Al-Jibori, S. A.; Habeeb, A. T.; Al-Jibori, G. H. H.; Dayaaf, N. A.; Merzweiler, K.; Wagner, C.; Schmidt, H.; Hogarth, G. Polyhedron 2014, 67, 338.

42. Sanchez, G.; Garcia, J.; Meseguer, D.; Serrano, J. L.; Garcla, L.; Perez, J.; Lopez, G. Inorg. Chim. Acta 2004, 357, 4568.

43. Griffith, D. M.; Bíró, L.; Platts, J. A.; Müller-Bunz, H.; Farkas, E.; Buglyó, P. Inorg. Chim. Acta 2012, 380, 291.

44. Oltean, D.; Pöllnitz, A.; Silvestru, A. Polyhedron 2013, $53,67$.

45. Gao, H. L.; Yi, L.; Zhao, B.; Zhao, X. Q.; Cheng, P.; Liao, D. Z.; Yan, S. P. Inorg. Chem. 2006, 45, 5980.

46. Aghabozorg, H.; et al. Polyhedron 2010, 29, 1453. 